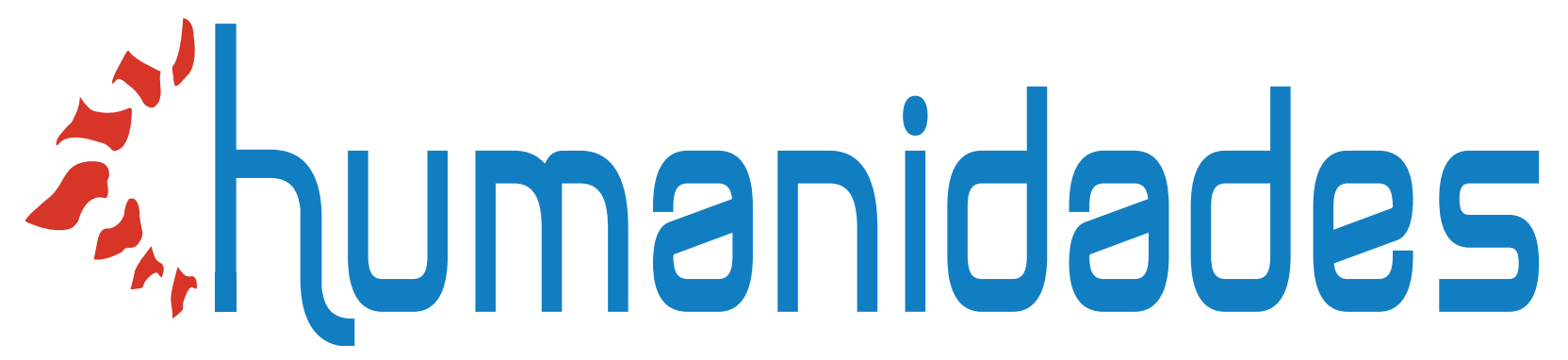

\title{
Despojo, resistencia y represión. Revueltas indígenas en el real de minas de Bolaños (Virreinato de la Nueva España) I734- I783
}

\author{
José Rojas Galván \\ Domingo Coss y León
}

\begin{abstract}
DOI: https://doi.org/I0.155 I7/h.v I0il.38583 https://revistas.ucr.ac.cr/index.php/humanidades/index




\section{"humanidades}

Revista Humanidades

ISSN: 2215-3934

humanidades@ucr.ac.cr

Universidad de Costa Rica

Costa Rica

\section{Despojo, resistencia y represión. Revueltas indígenas en el real de minas de Bolaños (Virreinato de la Nueva España) 1734-1783}

Rojas Galván, Dr. José; Coss y León, Dr. Domingo

Despojo, resistencia y represión. Revueltas indígenas en el real de minas de Bolaños (Virreinato de la Nueva

España) 1734-1783

Revista Humanidades, vol. 10, núm. 1, 2020

Universidad de Costa Rica, Costa Rica

Disponible en: http://www.redalyc.org/articulo.oa?id=498060395004

DOI: https://doi.org/10.15517/h.v10i1.38583

Todos los derechos reservados. Universidad de Costa Rica. Esta revista se encuentra licenciada con

Creative Commons. Reconocimiento-NoComercial-SinObraDerivada 3.0 Costa Rica. Correo electrónico:

humanidades@ucr.ac.cr/ Sitio web: http: //revistas.ucr.ac.cr/index.php/humanidades

Esta obra está bajo una Licencia Creative Commons Atribución-NoComercial-SinDerivar 3.0 Internacional. 


\section{Despojo, resistencia y represión. Revueltas indígenas en el real de minas de Bolaños (Virreinato de la Nueva España) 1734-1783}

$\begin{aligned} & \text { Dispossession, Resistance and Repression. Indigenous rebellions in the Real de Minas de Bolaños (Viceroyalty of the } \\ & \text { New Spain) 1734-1783 }\end{aligned}$
$\begin{array}{lr}\text { Dr.José Rojas Galván } & \text { DOI: https://doi.org/10.15517/h.v10i1.38583 } \\ \text { Universidad de Guadalajara, México } & \text { Redalyc: http://www.redalyc.org/articulo.oa? } \\ \text { joserogal@yahoo.com.mx } & \text { id=498060395004 }\end{array}$

(iD http://orcid.org/https://orcid.org/0000-0002-

0378-1792

Dr. Domingo Coss y León
Tecnológico de Monterrey, México
domingo.coss@itesm.mx

(iD) http://orcid.org/https://

orcid.org/0000-0002-1959-4887

Recepción: 06 Abril 2019

Aprobación: 17 Junio 2019

\section{Resumen:}

La crisis económica por la que atravesaba la corona española durante la segunda mitad del XVIII, la condujo a otorgar amplias prerrogativas a particulares interesados en la explotación de minas en la Nueva España, pues de ello dependía la reactivación de la exigua economía imperial. El objetivo es analizar los factores socio-históricos que motivaron a una serie de comunidades indígenas asentadas en las inmediaciones del Real de Minas de Bolaños a sublevarse en contra del poder durante el periodo 1734-1783. La metodología utilizada en este trabajo es la síntesis histórica, la cual aporta elementos para reconstruir los sucesos del pasado sobre la base de las fuentes -vestigios y testimonios- ya criticados. Lo anterior permite concluir que las revueltas fueron el resultado de la explotación de mano de obra indígena y la usurpación de tierras comunales que mineros españoles llevaron a cabo para cubrir las necesidades de las minas. Esto, bajo el beneplácito y soporte de la administración colonial. Asimismo, se concluye que con dicho despojo se dio inicio al proceso de conformación de la clase campesina asalariada en el norte neogallego.

Palabras Clave: Conflicto social, Poder político, Minería, Indios.

\section{Abstract:}

The economic crisis the Spanish crown was going through during the second half of the 18th century, led to granting of broad prerogatives to individuals interested in the exploitation of mines in New Spain, since it depended on the reactivation of the meager imperial economy. The objective is to analyze the socio-historical factors that motivated a series of indigenous communities settled in the vicinity of Real de minas de Bolaños to revolt against power during the period 1734-1783. The method used in this work is the historical synthesis, which provides elements to reconstruct the events of the past on the basis of the sources research and testimonies- already criticized. This allows us to conclude that the rebellions were the result of the exploitation of indigenous labor and the dispossession of communal lands that Spanish miners carried out to cover the needs of the mines, under the blessing and support of the colonial administration. Furthermore, it is concluded that with this dispossession, began the process of conformation of the salaried peasant class in the north of New Galicia.

KEYWORDS: Social conflicts, Political power, Mining, Amerindians.

\section{ANTECEDENTES}

Cuando Soriano (1994) afirma que las sublevaciones de indios que se presentaron en diferentes regiones del virreinato de la Nueva España son muestras palpables de la inconformidad de los indígenas, de su devenir 
histórico plagado de resentimientos y de un constante proceso de explotación, pero también del despojo de sus tierras (p. 20). De esta manera, Soriano está planteando la existencia de un interesante y complejo proceso, donde las prácticas de resistencia y represión se manifestaron en diferentes contextos e intensidades.

En consecuencia, investigar sobre la historia de las revueltas indígenas en el real de minas de Bolaños, supone el planteamiento de una serie de interrogantes: ¿Cuáles fueron las motivaciones que condujeron a las comunidades indias asentadas en las inmediaciones del Real minero de Bolaños a rebelarse en contra del poder durante la segunda mitad del siglo XVIII? ¿Qué tipo de acciones se realizaron para sofocar dichas rebeliones? ¿Cómo se generaron y expresaron las sublevaciones indígenas en dicho espacio? Asimismo, nos preguntamos ¿Cuáles fueron las medidas legales que emplearon los indígenas para hacer valer su derecho sobre la tierra? ¿Cuál era el significado de esta para los grupos indios? ¿Lograron recuperarlas? o en contraparte, ¿Las reformas implementadas por los borbones en el siglo XVIII, para lograr hacer más redituable la actividad minera en Bolaños contribuyeron a acelerar el proceso de despojo de tierras indias? Y de ser así ¿Dicho proceso pudo haber contribuido a que se gestaran e implementaran nuevos mecanismos de control social y explotación con el objetivo de incorporar a los indios a las haciendas o ranchos como peones asalariados?

A fin de responder a las anteriores preguntas fue necesario recurrir a una serie de fuentes de primera mano que hacen referencia al Real de Bolaños, localizadas en el Archivo General de Indias, España; Archivo General de Simancas, España; Archivo General de la Nación, México; y en el Centro de Estudios de Historia de México.

En este artículo se plantea como objetivo principal: reconstruir los factores socio-históricos que propiciaron que algunos pueblos indios de las inmediaciones de Bolaños se rebelaran en contra de las injusticias y el despojo de tierras que desde el poder se gestaron en su contra a partir de la tercera década del XVIII. Como resultado, se contribuye al conocimiento histórico sobre el proceso de conformación de la clase campesina asalariada en dicho territorio.

Para lograr esto, ubicamos nuestro objeto de estudio en un arco temporal (1734-1783) que refleja un momento donde se presentó un inusitado auge de producción de plata en el Real de Bolaños, lo que contribuyó a aliviar los efectos de la crisis económica por la que atravesaba la Corona española. Al respecto, Ruiz (2014) destaca que durante dicho periodo la producción tuvo un pico importante de 1236823 marcos de plata. Asimismo, refleja la consolidación de una élite mediante su participación en la minería y el establecimiento de alianzas con la burocracia colonial para hacerse de mano de obra indígena y tierras comunales (p. 202).

En esa dirección, coincidimos con Ruiz en que algunos autores han destacado que la necesidad por parte del Estado colonial de menguar los costos de la fuerza de trabajo, con el fin de garantizar la rentabilidad de las empresas mineras, fue solventada a través del reclutamiento forzado de tandas de trabajadores originarios de comunidades cercanas o adyacentes a los centros mineros; todo esto a partir de la segunda mitad del siglo XVIII. Tal como aconteció con los tumultos o rebeliones indígenas de la zona minera de Actopan, Hidalgo (Von Mentz, 1998 y Ruiz, 2007, p. 4).

Por lo anterior, es necesario destacar que previo a dicho periodo la producción argentífera en el virreinato de Nueva España, y en particular en Bolaños, no era significativa -a excepción de algunos reales mineros como Guanajuato, Zacatecas o Pachuca-. En consecuencia, el gobierno español se propuso llevar a cabo un plan de reformas para lograr que los diferentes reales de minas generaran mayor riqueza, pues de esto dependía que se mantuviera en el conjunto de monarquías que dominaban en el ámbito internacional. Es decir, Inglaterra, Francia y España.Por ello, en la presente investigación se parte del supuesto de que, la crisis económica por la que atravesaba la corona española a mediados del XVIII, la condujo a otorgar amplias prerrogativas a particulares interesados en la explotación de minas. En el caso del virreinato de la Nueva España otorgó beneficios y exenciones a españoles dispuestos a invertir grandes cantidades de dinero para reactivar la exigua minería. El Real de Bolaños en una muestra clara de dicha política reformista, pues contribuyó a que se 
generarán las condiciones para el arribo a dicho lugar de un grupo de peninsulares interesados en enriquecerse mediante la explotación de minas de plata, de la tierra y la mano de obra indígena.

Lo anterior trajo como consecuencia que los indios de la región se sublevaran en contra de los abusos y despojo de sus tierras cultivables o boscosas, pero también, se manifestaron fuertemente apelando a un viejo acuerdo que establecieron con la corona, el cual les otorgaba una serie de privilegios: tierras a perpetuidad, exención de alcabalas, montar a caballo, entre otros. Todo por su apoyo en la pacificación de la zona chichimeca a finales del XVI. No obstante, para la corona dicho pacto ya había perdido vigencia para la segunda mitad del XVIII, y optó por apoyar a los mineros debido a la urgencia por fortalecer la economía del imperio. Como resultado, los indígenas perdieron sus tierras y se vieron obligados a vender su mano de obra en las haciendas y ranchos que se conformaron a partir del despojo. En otras palabras, estamos ante el inicio del proceso de conformación de la clase campesina asalariada en el territorio norteño.

Van Young (1991) demuestra lo anterior para el caso de la población indígena del norte de Yucatán, la cual a finales del XIX se proletarizó fuertemente como resultado de la intensa actividad productiva de las haciendas henequeneras. En consecuencia, las comunidades indígenas de dicha región se debilitaron. En otras palabras, la región de Yucatán experimentó en dicho periodo lo que este teórico denomina como una "distorsión social" (p. 114). Es decir, estamos ante un proceso de despojo de tierras comunales de larga duración que abarcó buena parte de los siglos XVIII y XIX mexicanos.

Por lo antes señalado, se hace necesario realizar un balance historiográfico que permita identificar lo que se ha escrito sobre el Real de Minas de Bolaños. Es decir, cuáles son las temáticas y problemáticas que han interesado a los especialistas y cómo las han solucionado, así como los periodos y enfoques desde donde se han abordado. Y por supuesto, las preguntas que se plantearon los estudiosos y cómo fueron respondidas. Para así poder insertar esta investigación en la historiografía que ha contribuido a generar nuevo conocimiento histórico sobre Bolaños.

En primer lugar, se puede mencionar la investigación de Carbajal (1999), la cual arroja luz sobre la actividad del comercio en el Real durante el periodo que va de 1766-1810. El autor muestra de qué manera dicha actividad estuvo marcada por los ritmos de extracción de mineral, principalmente la plata. De igual manera, demuestra que en dicho periodo se fortaleció un grupo de comerciantes provenientes de la ciudad de México, quienes decidieron abrir tiendas en Bolaños, y la forma en la que algunos de los productos de consumo diario y artículos de lujo a la venta se importaban desde España. Todo esto en el marco de las reformas administrativas y la política comercial aplicadas por los borbones.

Carbajal (2002) realizó un estudio sobre la producción minera en Bolaños durante el periodo que va de 1748 a 1810. En dicha investigación se indaga sobre el status jurídico del minero, lo que permite al autor concluir que la Corona detentaba la propiedad de los yacimientos argentíferos, pero que mediante un acuerdo otorgaba concesiones a sus súbditos para su explotación. Asimismo, Carbajal destaca que su investigación resulta ser de suma importancia para comprender que los diferentes ritmos de la explotación minera contribuían a dinamizar la economía monetaria del virreinato de la Nueva España. En dicho entramado se hacen presentes formas de financiamiento, relaciones de conflicto, decisiones políticas y administrativas de gran calado. Por su parte, el enfoque teórico-metodológico que Carbajal utilizó es el de la ciencia social comprensiva. Las reflexiones finales van en la dirección de ampliar el conocimiento existente sobre la minería de la Nueva España a finales del periodo colonial.

Del mismo autor, una tercera investigación salió a la luz en 2008. El tema medular, la población de Bolaños durante los años que van de 1740 a 1848; en esta ocasión la obra trata temas como la dinámica demográfica, la familia y el mestizaje. Las fuentes utilizadas provienen de los archivos eclesiásticos del poblado de Bolaños y del archivo del arzobispado de Guadalajara. Los hallazgos reflejan que la dinámica demográfica variaba de acuerdo a la actividad minera, a mayor producción, mayor presencia de población española, mestiza e indígena. Otro de los hallazgos tiene que ver con el incremento del proceso de mestizaje que se dio como resultado de la llegada de una cantidad importante de personas de diferentes castas. 
Uno de los principales hallazgos fue la identificación de familias pluriétnicas constituidas por hijos de diferentes castas: lobos, mulatos, coyotes; esto como resultado del criterio del párroco a la hora de identificar los rasgos fenotípicos de los infantes, los cuales quedaron plasmados en los registros de bautismo. Aunque, como bien lo demuestra el autor, también había familias constituidas por indios o españoles. Carbajal concluye con un comentario relacionado con su interés por realizar un nuevo estudio sobre demografía histórica en un curato de la ciudad de Guadalajara de nombre Mexicaltzingo donde documentó la existencia de familias multirraciales. Es decir, abre la posibilidad de seguir indagando sobre dicho fenómeno social.

Por otro lado, Ruiz (2014) presenta un trabajo sobre el Real de Minas de Bolaños, Jalisco, en el siglo XVIII, la investigación aborda aspectos como las transformaciones territoriales y cambios sociales. Se muestra la forma en que la minería desarrollada en Bolaños durante dicho siglo constituyó un poderoso estímulo para sujetar el territorio adyacente a nuevas lógicas comerciales, que lo transformaron y tuvieron efectos diferentes en las comunidades indígenas situadas en el territorio del Gobierno de las Fronteras de San Luis de Colotlán. Un fenómeno multifactorial que desató conflictos sociales que se desplegaron en la región. El trabajo de Ruiz aporta importantes elementos, pues tanto la dinámica de la minería como la dinámica social se encuentran marcadas por el conflicto. Es decir, por las revueltas indígenas en dicho lugar.

Otro autor interesado en la historia de Bolaños es López (1974) quien realizó un artículo que trata sobre el establecimiento del Real de Minas de Bolaños. Esta investigación se plantea varios objetivos entre los que destaca: demostrar el espacio histórico en el cual se fundó el Real de Minas de Bolaños, así como también mostrar cómo fue que el Real llegó a convertirse en un real de minas con Caja Real, cuya influencia se dejó sentir en toda la zona occidental del reino de la Nueva Galicia y su capital Guadalajara. Para lograr dichos objetivos, López se vale de fuentes primarias que localizó en el Archivo General de la Nación (México), las cuales no habían sido trabajadas hasta ese entonces.

López destaca que en el año de 1750 Bolaños presentaba una inusitada bonanza, por ello se fueron haciendo más copiosas las demandas de los vecinos, mineros y autoridades, al virrey conde de Revillagigedo para que decidiera por sí mismo o consultara al rey la suerte que debería correr el nuevo real de minas; ante estas emergencias, el virrey informó al monarca Fernando VI la necesidad de crear instituciones que resguardasen los intereses de la Corona y organizasen la vida de aquella multitud de gentes que se había congregado en forma alarmante en el lugar desde 1748.

Finalmente, fue hasta finales de 1754 cuando se logró establecer como corregimiento. El descubrimiento de ricos yacimientos de plata condujo a las autoridades coloniales a generar las condiciones para que el Real se constituyera, al punto de contar con Corregidor y una Caja Real. Pero, además, el virrey Revillagigedo demarcó la jurisdicción territorial y administrativa que le debía corresponder, esta situación provocó reclamos por parte del presidente y oidores de la Audiencia de Guadalajara, quienes vieron afectados sus intereses en dicho lugar, pues el virrey dispuso que dicho Real estaría en adelante bajo la autoridad del propio virrey de la Nueva España. Es decir, López demuestra que Revillagigedo hizo todo lo que estuvo a su alcance para crear el gran Corregimiento de Bolaños.

El análisis de las anteriores obras permite señalar que la producción de conocimiento histórico generado sobre el Real de Minas de Bolaños es escasa si se compara con otros centros mineros de la Nueva España, tal es el caso de Guanajuato, Zacatecas o Real del Monte-Pachuca. Además, son pocos los especialistas que han investigado Bolaños, las temáticas abordadas se relacionan con su fundación como corregimiento, la producción minera, el comercio, la demografía y, en menor medida, con la presencia de conflictos sociales que se desplegaron en la región como resultado de la explotación minera, como bien lo demuestra Ruiz (2014). Por esto último, es que resulta pertinente la investigación que se presenta, la cual da cuenta de procesos de despojo de tierras y represión que llevaron a cabo los ricos mineros de Bolaños en contra de la población indígena asentada en los alrededores de dicho Real, como resultado se desarrollaron una serie de revueltas indígenas que pusieron en alerta a los mineros y a las propias autoridades coloniales. 
De esta manera, este trabajo toma como referencia teórica la perspectiva de la historia social de la rebelión permitiendo, en paralelo, el acceso hacia un conocimiento activo del pasado. Se propone desentrañar y, a la vez, hacer evidentes las injusticias que han padecido los sectores sociales marginados a través del tiempo, en este caso el despojo de tierras a las comunidades indígenas de la región de Bolaños localizada en el centro de lo que fue el territorio de El Gobierno de Colotlán- pero también las formas de resistencia generadas por ellos mismos para enfrentar el poder. Concordamos con Tuñón de Lara en cuanto a que: "En el centro de su problemática [de la historia social] se halla la historia de la conflictividad social en todos sus matices" (1984, p. 5).

Como parte del marco teórico los conceptos que contribuyeron a la articulación del problema de investigación son: revuelta, despojo y poder. Además, tómese en cuenta el empleo como similares de los siguientes términos: revuelta, sublevación, rebelión, levantamiento y alzamiento, tumulto. Avalando la idea de Soriano (1994), revuelta es "toda reacción directa, inmediata y espontánea a una vejación precisa" (p. 26). Se ha considerado descartar el concepto de insurrección por considerar que este es un movimiento encaminado a trastocar el orden establecido, es decir, sus objetivos son mucho más profundos. En otras palabras, las diversas sublevaciones aquí analizadas no tuvieron como objetivo fracturar el orden social establecido.

En consecuencia, la reconstrucción de los factores socio-históricos que propiciaron que algunos pueblos de indios de la región minera de Bolaños se rebelaran en contra del poder por el despojo que sufrieron de sus tierras y los abusos cometidos en sus personas resulta de gran utilidad, pues proporciona herramientas complementarias para el análisis de dicho grupo social que buscó a través de sus prácticas de resistencia aminorar las consecuencias del embate que el imperio español se empeñó en ejercer en su contra.

Para desarrollar esta propuesta, el documento está organizado en apartados. En el primero, y a manera de antecedentes, se da cuenta de las razones político-sociales y económicas que condujeron al gobierno español a la conformación de El Gobierno de las Fronteras de San Luis de Colotlán a finales del siglo XVI. Se muestra de qué manera, a partir de la fundación de dicha jurisdicción, al conjunto de pueblos de indígenas aledaños (Real de minas de Bolaños), les fueron otorgados una serie de privilegios: tierras a perpetuidad, fuero militar, exención de alcabalas, portar armas, montar a caballo, entre otros. Esto como resultado del apoyo otorgado a la Corona para apaciguar el inestable norte novohispano.

En el segundo apartado, se muestra como la política de incentivación a la minería de los borbones generó las condiciones para que se presentaran un conjunto de revueltas indígenas en el noroeste novohispano cuyo origen se encuentra en los abusos cometidos por los militares acantonados en el territorio, pero también por el despojo de tierras indias por parte de españoles. En el tercer apartado se reconstruyen los aspectos sociohistóricos que dieron origen a un conjunto de revueltas indígenas en el Real de Minas de Bolaños. Por último, se presentan las conclusiones de la investigación.

\section{A MANERA DE ANTECEDENTES}

El avance que emprendieron los españoles hacia el norte del virreinato de la Nueva España, durante la segunda mitad del siglo XVI, se debió al incentivo de los ricos yacimientos argentíferos localizados en las entrañas de la Gran Chichimeca, un vasto territorio señoreado por grupos indios nómadas o seminómadas conocidos durante la época colonial como chichimecas, quienes se caracterizaron por su valentía y fortaleza física a la hora de combatir a los peninsulares. La Guerra Chichimeca (1550-1590) obligó a los europeos a llevar una vida arriesgada, a sostener largas y crueles luchas contra los indios indómitos que no aceptaban ser despojados del territorio que señoreaban, ni a amoldarse a las faenas que los blancos les requerían.

La Guerra Chichimeca no solamente puso en peligro el transporte de plata de Zacatecas a la ciudad de México, sino que también obstaculizó las actividades mineras en otras regiones, como sucedió con la mina de Tepeque, al norte de Bolaños, que fue descubierta en el año de 1550, pero no pudo ser explotada sino 
hasta que los indígenas que habitaban cerca pudieron ser sometidos en 1590. Es a partir de 1595 cuando Bolaños y las cercanas minas de Tepeque pasaron a ser dominados por el gobierno virreinal, con la formación de una nueva y especial jurisdicción conocida como el Gobierno de las Fronteras de San Luis de Colotlán. El centro administrativo de dicha jurisdicción fue la recién fundada población del mismo nombre (Zingg, 1988, p.13), y de esta manera la participación de un grupo de cuatrocientos indios casados de Tlaxcala, como colonizadores y protectores, fue la clave para apaciguar la zona de guerra. Los acuerdos entre el virrey Luis de Velasco y los indios principales de Tlaxcala quedaron manifiestos en las capitulaciones que el monarca español Felipe II expidió el catorce de marzo de $1591^{1}$.

En ese sentido, y con base en la propuesta de Fábregas y Tomé (2002) de que las fronteras y las regiones son partes de las interrelaciones sociales o, si se prefiere, resultados de las mismas, podemos definir al Gobierno de las Fronteras de Colotlán como un espacio específico delimitado por fronteras, compuesto interculturalmente por españoles, indígenas, mestizos y otras castas, cuyas interacciones sociales en más de una ocasión cayeron en conflicto.

Así, los procedimientos de alianzas y tratados que generaron los españoles con sus indios aliados, los tlaxcaltecas, permitieron realizar la conquista de la Nueva Vizcaya y de Nuevo México a lo largo del XVII e inicios del XVIII, por lo que la frontera del Gobierno de Colotlán quedó atrás (Velazquez, 1961, p. 9). El hecho de que la frontera de Colotlán haya quedado rezagada, para nada significó que el gobierno español dejara en el olvido a dicha región fronteriza, pues en el centro de esta se localizaba uno de los principales centros mineros del virreinato, Bolaños. Por tanto, en esta zona se emplearon recursos materiales y humanos necesarios para su protección y explotación.

Al mediar el siglo XVIII, las desavenencias jurisdiccionales entre la Audiencia de Guadalajara y las autoridades de la capital del virreinato se complicaron, debido a que a partir de 1747, Bolaños comenzó un periodo de auge argentífero que despertó el interés de la Corona y de la capital del virreinato. La elevación de dicho Real a Corregimiento, en 1754, es una clara muestra de ello.

Las autoridades de la Audiencia de Guadalajara demostraron que no estaban dispuestas a que Bolaños fuera segregado de su autoridad porque iba en detrimento de sus intereses particulares. Asílo demostró José Basarte, entonces presidente de la Audiencia, quien dirigió una misiva a Fernando VI expresándole su malestar por la resolución tomada por el virrey Revillagigedo; el funcionario tapatío suplicaba al monarca que tomase “oportuna providencia para que el mineral de Bolaños vuelva a su antiguo estado y domicilio, sintiéndose su real clemencia de declarar si es facultativo al virrey el abrogarse a su gobierno todos los lugares que produjesen plata en abundancia" (Carvajal, 2002, p. 78).

Cabe destacar que el Real de Minas de Bolaños se localizaba en el norte de la Nueva Galicia, y estaban bajo su jurisdicción una serie de pueblos indios, ranchos y haciendas. Al respecto, Gerhard (1996) destaca que este Real de Minas constituía una circunspección rodeada casi en su totalidad por diversas comunidades indígenas, adscritas al territorio militar de las Fronteras de San Luis Colotlán, fue establecido en las cercanías de las antiguas minas de San Martín Tepeque y en el borde del Real de Santa Rosa, entre 1730 y 1735 (p. 95). (Véase Imagen 1). 


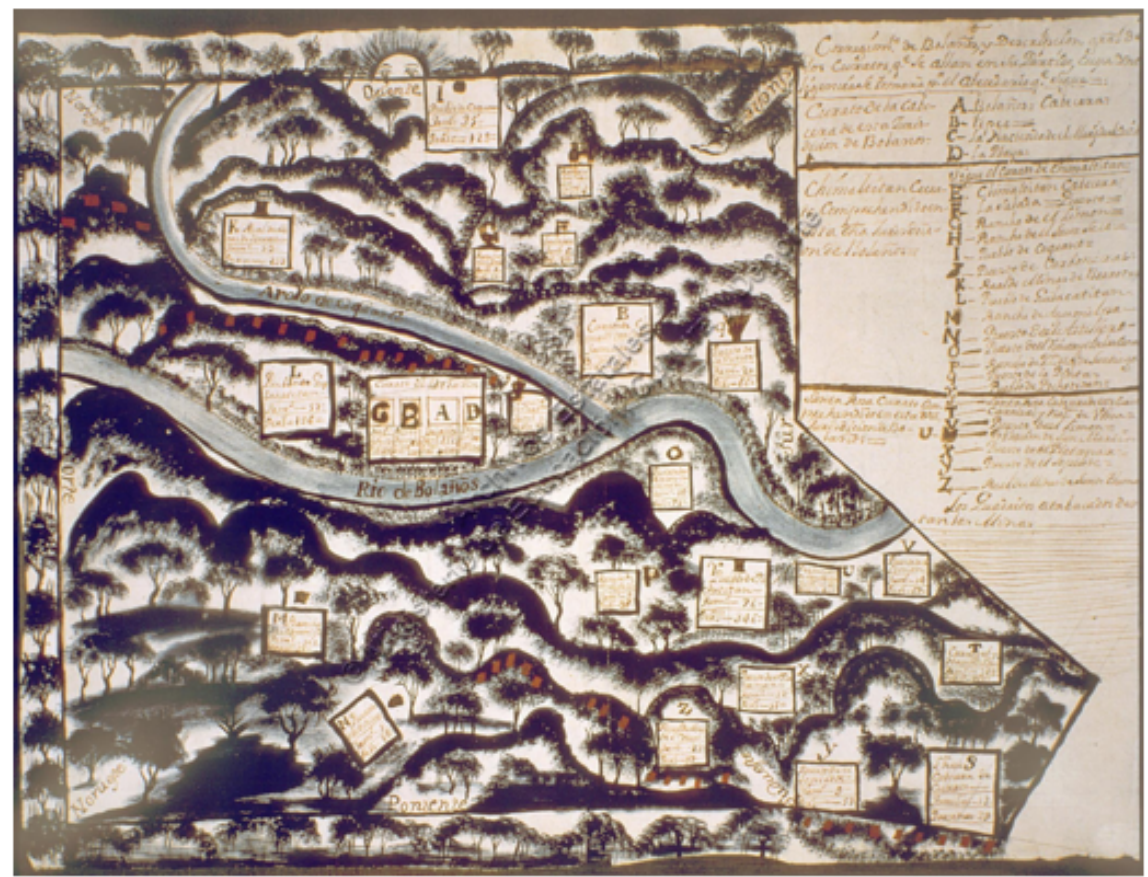

IMAGEN 1.

Mapa de la jurisdicción de real y minas de Bolaños, 1773

Archivo General de Indias, MP-MEXICO,293 - 1 - Imagen Núm: 1 / 1

\section{REBELIONES INDIAS EN EL SEPTENTRIÓN NOVOHISPANO}

Este apartado tiene como objetivo analizar un conjunto de factores de índole sociopolítico y militar que contribuyeron a que en el septentrión novohispano se suscitaran una serie de rebeliones indias, cuyo origen se encuentra, al igual que en Bolaños, en los abusos y despojo de tierras que los españoles cometieron en su contra. Dichas tierras debían servir para fortalecer actividades sustantivas como la agricultura, ganadería y minas. Por esto, podemos afirmar que la política de impulsar la economía por parte de los borbones se extendió a lo largo y ancho del territorio novohispano.

Dichas rebeliones fueron consideradas por los borbones como un peligro para sus intereses y, por tanto, los indios rebeldes fueron vistos como enemigos internos. Entre los levantamientos que se suscitaron en el norte novohispano a lo largo del XVIII se encuentran: los levantamientos de yaquis, pimas y mayos en Sonora de 1740, de pimas entre 1768-1770, y de apaches en Texas, levantados en 1758.

En lo que actualmente es el estado de Baja California, México, habitaron grupos seminómadas que se rebelaron en contra de los españoles debido a la actitud arbitraria de estos en las acciones aparentemente evangelizadoras. Los cochimíes en el norte y los pericúes en el sur se plantearon destruir todo rasgo de la religión cristiana, mediante una insurrección que estalló en 1735, arrasando cuatro misiones. La represión de los colonizadores fue tal, que quedaron solamente 400 indígenas de 4 mil que iniciaron la rebelión. Los yaquis que poblaban el territorio de lo que hoy día es el estado de Sonora se rebelaron en 1740 incendiando iglesias e imágenes. Posteriormente, derrotaron a una tropa en un pantano en una acción de guerrilla, pero más tarde la sublevación fue dispersada y las fuerzas coloniales abatieron a más de 1600 rebeldes indígenas (Enríquez, 2011).

La historia de la dominación española sobre los distintos territorios novohispanos nos muestra que hubo aniquilaciones masivas de poblaciones nativas, pero también destrucciones culturales irremediables, como en los casos arriba señalados. 
El origen de estas sublevaciones puede rastrearse, al igual que la gran mayoría de otras partes de los reinos del imperio español, en el despojo de su territorio y de los abusos cometidos hacia sus habitantes y bienes comunales por parte de los grupos de poder. Las reformas borbónicas buscaron fortalecer la frontera norte ante el avance de rusos, franceses, ingleses, mediante el envío de militares. Esto provocó una alteración de la dinámica social de los indios de la región.

Coss y León (2000) refiere que en Sonora, en el siglo XVIII, la población indígena y los españoles (tanto militares, misioneros religiosos y civiles) se encontraban en constantes conflictos. Pueblos indios como los seris, pimas, yaquis y apaches se oponían a la presencia española en la región norte, y ya desde el siglo XVI, con las primeras incursiones europeas, se habían mostrado reacios a la acción colonizadora que intentaban las avanzadas misioneras a cargo de los jesuitas, quienes practicaban la labor misionera a partir de congregaciones en las que se alentaba la sedentarización de los indígenas y su gradual cristianización, así como también la enseñanza de oficios y la agricultura. No obstante, por un lado, la belicosidad de los indígenas; y por otro, los constantes conflictos entre las autoridades militares de la provincia y los misioneros en cuanto a la estrategia a seguir para la pacificación y sometimiento de los naturales a la autoridad colonial, generaron como resultado que Sonora fuera una región de constante inestabilidad.

Esto incitó a la corona española a reforzar su presencia en este vasto territorio. Para lograr su objetivo, se solicitaron informes desde la capital del virreinato de la Nueva España. El resultado: una vasta cantidad de documentos fueron enviados a la ciudad de México y a la corte en Madrid, en los que se hablaba con testimonios de misioneros y autoridades militares del estado que guardaba la provincia.

La situación de inestabilidad se acentuó a mediados de siglo con el alzamiento seri de 1750, y es a partir de este momento donde el conflicto entre misioneros jesuitas y autoridades militares se agudiza. La presencia del capitán Diego Ortiz de Parrilla como gobernador de la provincia a partir de 1749 hasta 1753, marca el periodo en que la sublevación indígena se generaliza en la zona.

La siguiente tabla es una muestra clara de lo argumentado por Coss y León, cuyo contenido refleja la situación de inestabilidad en la región de Sonora, la cual se veía también manifiesta en el norte neogallego, específicamente en la región de Bolaños (Véase Tabla 1).

Tabla 1.

Tabla 1. Rebeliones indigenas en el noroeste, $1700-1768$

\begin{tabular}{|l|l|c|}
\hline TRIBU & LUGAR & AÑOS \\
\hline Seris & Sonora & 1725 \\
\hline Pericúes & California & 1734 \\
\hline Pimas Bajos & Tecoripa y Suaqui & 1737 \\
\hline Yaqui & Sonora & 1740 \\
\hline Seris & Sonora & 1749 \\
\hline Pimas y pápagos & Sonora & 1751 \\
\hline Seris & Sonora & $1760-1764$ \\
\hline Seris & Sonora & $1766-1768$ \\
\hline
\end{tabular}

Fuente: Sergio Ortega Noriega. Historia General de Sonora, T. I. p. 66. Cit. Por Coss y León, p. 4. 
Como se señaló líneas arriba, existían noticias de la presencia de minas en la región del cañón del río Bolaños desde mediados del XVI, estas no fueron explotadas de forma sistemática por la poca cantidad y calidad del metal encontrado; no obstante, el lugar comenzó a adquirir verdadera importancia a partir de 1734, pues en este año se descubrieron las minas de Bolaños, lo que provocó una interesante reactivación económica y flujo de las mercancías. Para Ruiz Medrano (2014), esta serie de cambios económicos, derivados del auge de Bolaños, comenzaron a constituir factores de presión sobre algunas comunidades indígenas asentadas en la zona (p. 203).

Las Imágenes 2 y 3 que a continuación se presentan permiten ubicar el escenario donde se llevaron a cabo los hechos arriba narrados. Pero también, los que se relacionan con las revueltas indígenas en el Real de Bolaños durante buena parte del siglo XVIII.

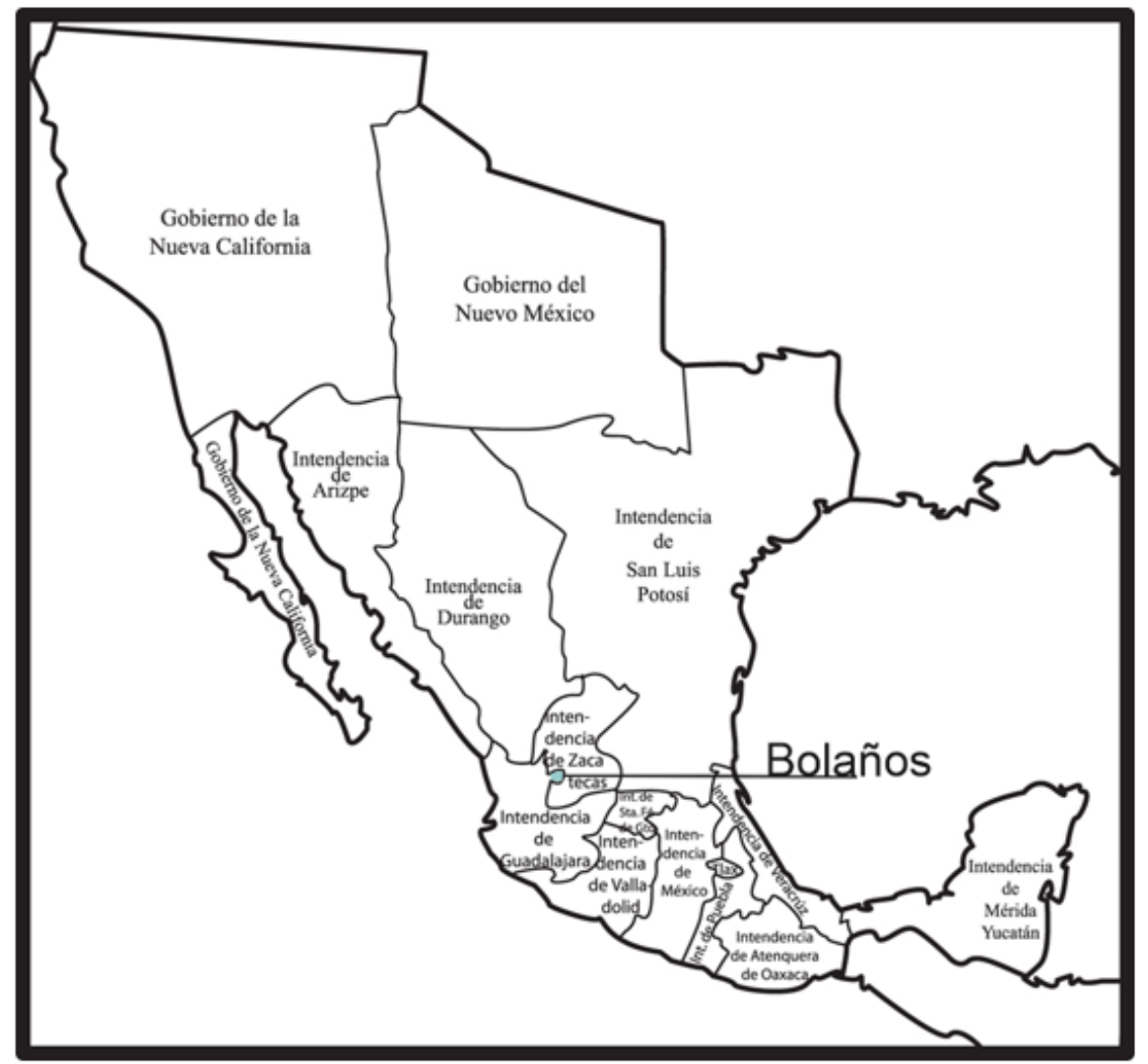

IMAGEN 2.

Las Intendencias de la Nueva España (1786)

Reelaborado por los autores en base a: "Las doce Intendencias (segunda división) y los Gobiernos de las dos Californias, el Nuevo México y Tlaxcala a principios del siglo XIX". En: Edmundo

O’Gorman. Historia de las divisiones territoriales de México. México: Editorial Porrúa, 2000, p. 33. 


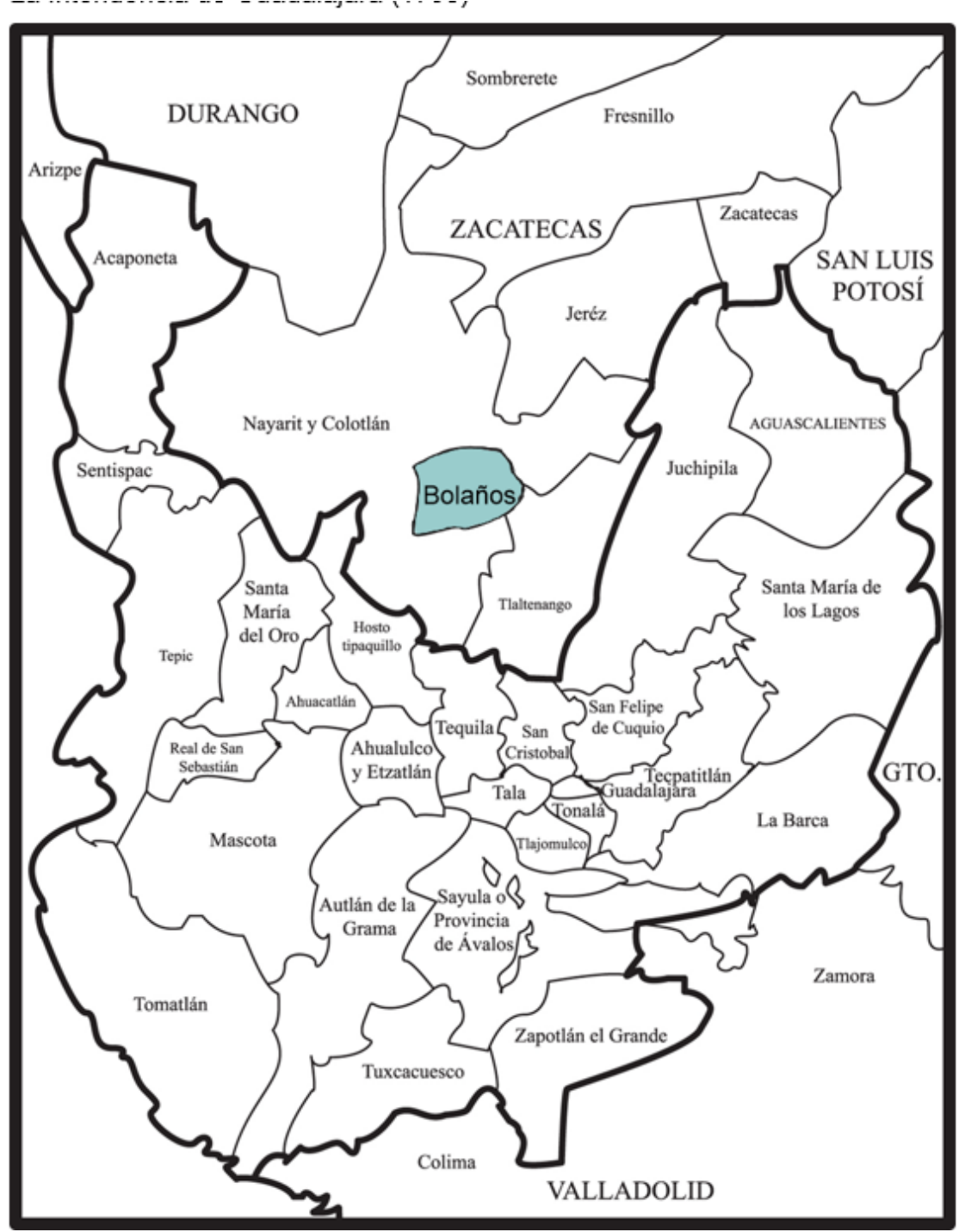

IMAGEN 3.

La Intendencia de Guadalajara (1793)

Reelaborado por los autores utilizando: "La Intendencia de Guadalajara según la visita de Menéndez Valdés (subdelegaciones y Cabeceras) (1793)”. En: María de los Ángeles Gálvez Ruiz. La conciencia regional en Guadalajara y el gobierno de los Intendentes (1786-1800). Guadalajara: Gobierno del Estado de Jalisco, 1996, p. 77.

\section{Revueltas indígenas en el Real minero de Bolaños}

La mayoría de las rebeliones indígenas que se suscitaron en la zona minera de Bolaños, tuvieron el carácter de revueltas en contra de autoridades o medidas del gobierno, y por supuesto, en contra de la ambición de los particulares por sus tierras.

Las fuentes dan noticia de que la principal razón por la cual se suscitaron una serie de revueltas durante buena parte del XVIII, fue el despojo que sufrieron los indios de sus tierras fértiles y boscosas, principalmente por los mineros de Bolaños y hacendados. Es decir, la escasez de dicho bien propició el enfrentamiento entre dos grupos sociales donde cada uno de ellos hizo valer sus argumentos y derechos ante el gobierno colonial para preservar las tierras aptas para el pastoreo y para el cultivo de granos de consumo humano y animal.

La historia de todo régimen absoluto y la historia de la conspiración son dos historias paralelas que se remiten de manera mutua. Donde se localiza el poder secreto, se encuentra, casi como su producto natural, 
el contrapoder, igualmente secreto, en forma de conjuraciones, complots, o bien de sediciones, revueltas o rebeliones, preparadas en lugares impracticables o inaccesibles (Villamil, 1996; Gilabert, 2002, p. 159).

Así pues, es a partir del ascenso del auge minero de Bolaños en la tercera década del XVIII, cuando la interrelación social de los grupos de poder y contra poder ${ }^{2}$ de la zona cayó en crisis por la disputa de las tierras agrícolas y bosques de los indígenas.

Los documentos de la época dan cuenta de un número importante de casos en los que los indios norteños se rebelaban por los abusos que cometían los españoles en su contra, así sucedió en el año de 1735, cuando un grupo de indios del pueblo de Huejúcar, ante la posibilidad de perder sus tierras comunales que tenían arrendadas al español Pedro de Nava, acudieron a la ciudad de Zacatecas ante el Teniente de Corregidor Lucas Alonso y Valle, para solicitarle la reproducción y certificación de sus títulos de propiedad territorial que, por razones de uso y del paso del tiempo, se encontraban en mal estado, pues databan del siglo XVI ${ }^{3}$. El hecho de que los indígenas de Huejúcar conservaran sus antiguos escritos y que, además, buscaran la reproducción de los mismos, no solo comprobaba que eran los legítimos dueños, sino que, además, significaba la conservación de la memoria histórica de su pueblo. Pero también, se puede argumentar que los de Huejucar eran poseedores de una conciencia histórica ${ }^{4}$, que constantemente era reforzada mediante la exposición de dichos títulos ante las autoridades coloniales que podían cuestionar la autenticidad y legitimidad de sus títulos. En ese sentido, Cataño (2011) afirma que la conciencia histórica rememora al pasado como un espejo de la experiencia, en el cual se refleja la vida presente y sus características temporales son, así mismo, reveladas (p. 229).

La práctica de los indios fronterizos de arrendar sus tierras comunales a españoles, se daba con la intención de obtener algunos ingresos para el funcionamiento de los cabildos indianos, que se encontraban en un marco permanente de carencia de recursos (Enciso, 2000, p. 38).

Las diligencias sobre la querella se llevaron a cabo en buenos términos en favor de los indios, ya que, por medio de la documentación presentada por los afectados, se comprobó que los verdaderos propietarios de las tierras en cuestión eran precisamente los indios de Huejúcar (Rojas, 2009, p.103).

Además, el virrey Juan Antonio Vizarrón y Eguiarreta, arzobispo de México, ratificó la fidelidad de los indios a la Corona, así como sus privilegios de militares y fronterizos, ya que habían observado con puntualidad la disciplina militar y obediencia a su jefe, en toda ocasión que se había requerido. Especialmente en la sublevación de más de veinte pueblos fronterizos en el año de 1705, donde los indios de Huejúcar acudieron con sus armas y caballos a someter a los sublevados ${ }^{5}$.

El levantamiento al que hacía referencia el virrey obispo, había tenido graves repercusiones en la zona fronteriza, pues a raíz de la poca respuesta a los litigios que sobre tierras tenían varios pueblos de indios con españoles, acaeció no solo la quema de viviendas de los blancos y el robo de sus pertenencias, sino también la muerte del capitán protector Silva, en manos de los indios de Nóstic, en 1705 (Pérez Verdía, 1988, pp. 319-320). En consecuencia, la respuesta por parte de los peninsulares y de los indios aliados de Huejúcar, como lo señalaba el virrey, fue terrible para los rebeldes.

Las coaliciones que se dieron entre españoles y algunos indios fronterizos, implicó beneficios para ambas partes. Así lo demostró el virrey Marqués de Casafuerte, cuando revalidó a los indios de San Juan Bautista de Mesquitic sus privilegios militares, por su ayuda en la empresa de conquista militar que se realizó en la provincia del Gran Nayar, en el año de 1722 (Rojas, 2009, p.104).

Los españoles y sus indios aliados del territorio de Colotlán en ocasiones respondían al llamado de la Corona para someter a cualquier grupo de indios sublevados, no solamente en la región fronteriza, sino allende sus fronteras, donde había importantes intereses mineros. Así se confirmó con la rebelión que se suscitó en Guanajuato, el $1^{\circ}$ de julio de 1767, la cual, se ha atribuido al descontento de la población por la expulsión de los jesuitas.

El entonces Visitador, José de Gálvez, previendo las posibles consecuencias de dicha rebelión, se dio a la tarea de proteger como fuera las minas de la región del bajío. Para esto, envió un comunicado al Corregidor 
de Bolaños, en julio de 1767 , en el que le ordenaba que reclutara el mayor número de gente armada posible, a efecto de dar un digno castigo a los sublevados

[...] y haviendolo puesto en execusion alisto y se alistaron voluntariamente mas de seiscientos hombres compuestos de Indios flecheros, españoles y Gente de Rason...quienes estando ya prontos a emprehender su marcha a expensas sullas repitio segunda carta...[el Visitador]..ordenando que no se moviesen de sus recidencias respecto a tener ya paciguada la provincia[... ${ }^{6}$.

La buena respuesta que dieron los habitantes de Bolaños y del resto de las fronteras de Colotlán al llamado de las autoridades coloniales, sin duda se debió al interés de los mineros por exterminar con cualquier intento de insubordinación que se presentara en las regiones mineras de cualquier parte del virreinato, puesto que, de llegar a extenderse, podría afectar los intereses que tenían en dicho real tanto la Corona como la élite de la región de Colotlán.

No obstante, los pactos de alianza que se dieron entre los indios y su capitán protector, llegaron a romperse por el incumplimiento de alguna de las partes, siendo por lo regular el capitán protector el primero en incumplir lo pactado. Tal como sucedió en el año de 1754, cuando un grupo de indios de Huejúcar pugnaron por que las elecciones de sus autoridades se realizaran en su pueblo y no en la cabecera, esto es, en Colotlán. El capitán protector, Juan Antonio Romualdo Fernández de Córdoba, no estuvo de acuerdo con el hecho ${ }^{7}$, debido a que era él quien decidía cuáles personas del pueblo tomarían los cargos de gobernador, y demás oficiales de República, y no los indios.

El cabildo de los diferentes pueblos de indios fronterizos, tenía como base la tradición de los tlaxcaltecas que llegaron a la región durante el siglo XVI. Ellos tomaron ambas tradiciones, la mesoamericana y la española, y lograron crear una institución diferente por medio de negociaciones y ofertas a la Corona. En el cabildo indígena de la región fronteriza, existía un gobernante que surgía de los barrios, renovable año tras año. De esta manera, se aseguraba la cohesión que proporcionaba el gobernante, pero además se promovía que los barrios tuvieran intercambio de burócratas, de esa manera, en el cabildo habría siempre personas de todos ellos (Dávila, 2001, pp.162-163). Es decir, se practicaba una democracia donde los cargos eran transferidos de forma equitativa.

En los documentos se puede percibir una intensificación de los levantamientos indígenas en el gobierno de Colotlán, a partir del auge minero que se presentó en Bolaños durante 1771, cuando el minero Antonio Vivanco tuvo una participación muy importante. La ambición de Antonio Vivanco por hacerse de nuevas tierras, lo llevó a incurrir en una serie de irregularidades, en perjuicio de la población india. Todo empezó cuando Vivanco, en contubernio con el entonces capitán protector de Colotlán, Felipe del Villar, quien era su compadre, fiador e íntimo amigo ${ }^{8}$, logró hacerse de una porción de tierra fértil del pueblo de San Lorenzo de Azqueltán, denominada La Ciénega, ubicada al suroeste de Colotlán y norte de Bolaños, en el año de $1778^{9}$.

Antonio Vivanco se valió de mecanismos de represión para posesionarse de La Ciénega, utilizando a sus "baqueros para que quemasen los jacales y las chosas que en el referido paraje tenían los naturales" y así formar "rancho para mantener y agostar [la] mulada [del] dicho don Antonio..." ${ }^{10}$.

Para Vivanco resultaba vital contar con las tierras de los de Azqueltán, pues sus minas demandaban un número crecido de mulas, caballos y reses. Por tal motivo, cuando se le ordenó restituir de inmediato dichas tierras argumentó ante las autoridades del centro del virreinato de que si las entregaba se ocasionaría graves daños al Real Erario ${ }^{11}$. Situación que hizo recapacitar al gobierno central con respecto a la decisión inicialmente tomada. A cambio se le ordenó a Vivanco pagar la renta correspondiente a los indios afectados si quería seguir manteniendo las tierras indias ${ }^{12}$.

Pero Vivanco no fue el único beneficiario de las tierras de los de Azqueltán, ya que Del Villar vendió una parte considerable de ellas a un español que se apellidaba Miranda, vecino de Tlaltenango ${ }^{13}$. Estos hechos, ocasionaron que los indios afectados comenzaran a buscar la forma de protegerse de los abusos de su capitán 
protector, pues Del Villar los había amenazado con ir personalmente a su pueblo a darles un escarmiento si continuaban oponiéndose a lo realizado por él.

Ante el temor de una represalia, los de Azqueltán, teniendo conocimiento de que los indios de Mesquitic y Nóstic gozaban de cierto favoritismo por parte de Del Villar, les escribieron solicitándoles su ayuda para que el día en que fuera dicho capitán, acudieran a interceder por ellos. Pero las misivas, de alguna manera, fueron a dar a manos del capitán, quien las interpretó como una sublevación o conjuración contra su persona. Razón por la cual los castigó despojándolos de una buena parte de sus bienes.

Los anteriores acontecimientos fueron denunciados por un grupo de indios caciques de la "nación" tlaxcalteca de la frontera de San Luis de Colotlán ${ }^{14}$ ante el virrey Bucareli, por medio del apoderado de los indios, el licenciado Jacinto Alarcón, en el año de 1777. Los indios destacaron, entre otras cosas, que desde que Felipe del Villar asumió el cargo de capitán protector, "han experimentado notables opresiones, angustias, y cuidados, a causa del modo con que se maneja y conduce en el ejercicio de su cargo dicho Felipe" 15 .

Del Villar, también fue acusado de abuso de poder en otros pueblos de la región de Colotlán, ya que, al igual que a los de Azqueltán, a los indios de Temastían los despojó de una parte de sus tierras nombradas la Mesa de Copete, que vendió a José de Contreras. Además, mandó tirar las mojoneras que tenían puestas como señal de dominio en sus respectivos linderos, con el pretexto de que el dinero que había obtenido de la venta era para remitirlo al rey.

Otra acusación en contra del dicho capitán, fue haber despojado a los indios del pueblo de Santiago Tlatelolco de una labor de maíz para sembrarla el Capitán por su cuenta. La posesión de esta tierra por parte de Del Villar, vino a causar grandes perjuicios a los indios, debido a que dichas tierras se ubicaban en una parte elevada y eran las que proveían de agua al pueblo, ocasionado incluso, la suspensión de la obra de construcción de la iglesia por falta de agua (Rojas, 2009, p. 109).

En total, eran siete pueblos de los veintiséis que comprendían la jurisdicción del Gobierno de las Fronteras de Colotlán, los que estaban obligados a sembrar y cosechar para el capitán Del Villar media fanega de maíz. En cuanto a los pueblos más distantes, en lugar de maíz, debían de pagar anualmente cada uno seis pesos, más ocho pesos por servicio personal ${ }^{16}$.

Las denuncias de los indios afectados, tenían como finalidad no sólo la defensa de sus intereses, sino también dejar mal parado a dicho capitán ante el virrey Bucareli, por lo que denunciaron los excesos y faltas a su empleo de protector de las fronteras, pues desde el cinco de junio de 1776, en que Del Villar había tomado posesión de su empleo, estuvo en Colotlán tan sólo cinco días pues, el diez del mismo mes, se retiró a la Villa de Aguascalientes, y no volvió hasta el veintisiete de agosto para asistir a las fiestas que él mismo dispuso ${ }^{17}$. La decisión del capitán protector de trasladarse a la villa de Aguascalientes se debía, sin duda, a las comodidades que ofrecía dicho lugar a los españoles.

Los caciques indios señalaron al virrey que, concluidas las festividades, Felipe del Villar decidió cambiar su lugar de residencia de Colotlán a Aguascalientes. Para tal efecto, dio órdenes a don José de Santiago Celis, gobernador del barrio de Tlaxcala, en Colotlán, para que:

[...] remitiese mulas con todo el avio necesario y carretas en que conducir todos sus muebles y considerable [número] de gente de servicio tanto para los fines expresados como para que trayeran cargadas en los hombros aquellas prendas del omenage de cassa que podrían maltratarse viniendo sobre las mulas o carretas...sin embargo no hubo pago de los fletes de mulas y carretas, ni menos ministró cosa alguna, aun para sus precisos alimentos a todos los individuos que se ocuparon en el destino expresado[... $]^{18}$.

Además de las anteriores exigencias, Del Villar ordenó al gobernador Celis, a principios de agosto de 1776, que se juntasen cincuenta hijos de cada pueblo de la frontera: en total mil cuatrocientos hombres, con sus banderas, para que en enero del siguiente año recibieran a su mujer en las afueras de Colotlán, a quien titulaba "la señora generala" ${ }^{19}$. 
Concluido el recibimiento de gala hecho por los indios de Colotlán, Del Villar ordenó inmediatamente que se hiciesen fiestas de toros, convocando para ello a todas las personas de los alrededores. Después, se continuó con juegos prohibidos como Albures, Chuza: Bolichi, tanto en las Casas Reales como en la plaza pública, y que por otorgar dichas licencias, el capitán recibió cien pesos ${ }^{20}$.

Así, pues, los recursos obtenidos por los festejos en Colotlán fueron a parar a los bolsillos de Del Villar, situación que sin duda vino a ensombrecer aún más el panorama social de la cabecera. Ante la ausencia de ingresos al cabildo es posible imaginar el estado del lugar: calles sucias, puentes a punto de caerse, constantes epidemias debido a las malas condiciones sanitarias, incluso, el techo del cabildo podía tener goteras.

Las denuncias de los indios repercutieron de manera importante en el gobierno de Colotlán, ya que dieron pie para que el gobierno central pusiera atención en el desempeño de Del Villar. Lo primero que hizo el virrey fue comisionar al Alcalde Mayor de Jerez, Antonio de Jáuregui, el dieciocho de noviembre de 1777, para que realizara las pesquisas correspondientes al caso. Jáuregui dispuso que Del Villar se retirara de las fronteras hasta nueva orden, con la intención de que su presencia no influyera en los testimonios que debía recabar el comisionado.

$\mathrm{Al}$ retirarse Felipe del Villar de la zona fronteriza, hubo la necesidad de instalar a un funcionario sustituto que quedara al frente del gobierno de Colotlán. Para tal efecto, el virrey decidió que el más idóneo era Luis Méndez de Liébana, teniente de caballería del Presidio de Nayarit, quien quedó al frente de Colotlán, y el propio Nayarit (Rojas, 2009, p. 111).

El nuevo capitán protector tomó partido en el conflicto en favor de los indios caciques que tenían demandado a Del Villar. Méndez de Liébana, con la intención de dar seguimiento al litigio en contra de Del Villar, se dedicó, en contubernio con sus adeptos, los indios Juan de Córdoba, Calixto Pacheco y otros, a exigir fuertes cantidades de dinero que pasaban de seis mil pesos a los naturales de la frontera para dar seguimiento al juicio de Del Villar, a los que no contribuían los encarcelaba y les embargaba sus bienes. Tal como lo hizo con todas las tierras del pueblo fronterizo de Ostoc, que fueron vendidas a un vecino del Real de Bolaños de nombre Antonio Pérez, por la cantidad de treinta marcos de plata (Rojas, 2009, pp. 111-112).

Ante los abusos de Méndez de Liébana, el gobernador y otros indios de Santiago Acaspulco se rebelaron, incluso contra su propio párroco, el Bachiller Isidro de Espino, cuando en defensa de un indio de nombre José Apolinario, partidario de Del Villar, que se había refugiado en la iglesia del pueblo, intentaron golpearlo en la cabeza con un palo, y echarle un lazo para arrastrarlo ${ }^{21}$.

El indio Apolinario, con la finalidad de escapar de sus agresores, fue a refugiarse en lo alto del altar mayor del templo. Pero de ahí fue bajado a palos, y cuando el sacerdote intentó detenerlos, haciéndoles ver el respeto que se debía al lugar sagrado, y venerable atención a las divinas imágenes, respondiéndole estas palabras: “(...) que Santos, ni que porquerillitas que aquí no mandan ellos si no nosotros" 22 .

$\mathrm{Al}$ enterarse los indios de una muy probable represión por parte del capitán Méndez de Liébana, por lo menos tres pueblos de la frontera (Huejúcar, Santa María y Acaspulco), quedaron casi desiertos, ya que sus moradores se dieron a la fuga.

De tal manera, la situación en la frontera se tornó más complicada, ante la división de los pueblos fronterizos en dos bandos: "al uno que llaman Villaristas y Padreros y a el otro Liébanistas" ${ }^{23}$.La acción de estos dos bandos hizo que la autoridad virreinal pusiera más atención en el territorio de Colotlán. Por tal motivo, y debido a la denuncia que pusieron los indios de Acaspulco en contra de Méndez de Liébana, este fue obligado, al igual que Del Villar, a retirarse diez leguas de distancia de las fronteras. Por lo que, de nueva cuenta, el gobierno de Colotlán quedaría sin un representante al frente.

El comisionado Jáuregui decidió entonces instalar interinamente a Manuel José de Aguayo "persona imparcial e idonea (sic) y actual vecino para que administre justicia hasta nueva orden" ${ }^{24}$. Sin embargo, Aguayo no aceptó dicho empleo por considerar que los alborotos eran causados por los malentendidos de las partes en disputa. En consecuencia, quedó al frente del gobierno el indio gobernador de $\operatorname{Colott}^{25}$. 
Las constantes sublevaciones en la región fronteriza y sus razones de ser, hicieron que el gobierno virreinal, en el año de 1791, iniciara la aplicación de un plan de reformas a la estructura del gobierno colotlense, entre las que se encontraba el repartimiento de tierras indias a españoles, con la intención de que los indios fueran más dóciles y con mejores sentimientos de religión, así como promover el florecimiento del comercio.

A este respecto, Shadow señala que en las comunidades de Huejúcar, Santiago Tlatelolco, y Santa María de los Ángeles, se dio una integración a la economía mercantil, desde 1780, y que, por tal motivo, estas comunidades indias fueron las primeras que perdieron sus tierras, su identidad y su cultura indígena (Shadow, 2000, p. 68). Así, en 1783, se señalaba que habitantes de algunos pueblos, como Santa María, Tulimique, Huejuquilla y Tlalcosagua, junto con las labores agrícolas apoyadas por una economía ganadera trashumante, también solían trabajar como sirvientes en las haciendas. En consecuencia, la integración de los indios de dichos pueblos a la economía mercantilista como empleados en las haciendas o en las minas, fue un logro de la política de los borbones, cuya finalidad era la de incrementar la producción del reino.

\section{Conclusiones}

En conclusión, prácticamente durante todo el período de vida del gobierno de Colotlán, se dio una presión sobre la tierra, sin embargo, con el despegue de la producción minera de Bolaños, a partir de la tercera década del XVIII, se aprecia una intensificación de la misma, debido a que los mineros españoles necesitaron de un mayor número de tierras cultivables y boscosas para cubrir las necesidades de sus minas.

Lo anterior, trajo como consecuencia que los mineros, en confabulación con funcionarios de la Corona, se dieran a la tarea de despojar a las comunidades indias asentadas en la periferia del Real minero de Bolaños y allende sus fronteras de sus tierras, haciendo uso de su influencia política, poder económico y militar.

En respuesta, los indígenas buscaron la forma de defenderse haciendo valer un añejo acuerdo que establecieron con la corona española a finales del XVI, el cual les brindaba, en teoría, todo el derecho sobre sus tierras. Sin embargo, a los mineros y al propio gobierno colonial no les importó pisotear dichas preeminencias por los beneficios que las tierras indias podían significar para las minas.

El sentimiento de pertenencia y arraigo de las tierras norteñas por parte de los indígenas y los españoles, como pudo apreciarse, es totalmente opuesto. En los primeros, se puede percibir un sentimiento de arraigo a sus tierras independientemente de si eran o no productivas, ya que estas formaban parte de su status de fronterizos. En contraste, para los segundos (poderosos mineros), la tierra era un elemento de prestigio, pero más que eso, un recurso estratégico por el cual buscaron tener abastecidas sus minas de alimentos, ganado y recursos madereros. Por lo que, una vez que las minas dejaban de ser productivas, las tierras cultivables ya no eran importantes. En consecuencia, las vendían a otros españoles con vocación de hacendados que sí tenían interés en ellas.

Estos dos distintos modos de concebir la tenencia de la tierra, ocasionaron una serie de revueltas indígenas que pusieron en alerta no solo a la élite minera, sino al mismo gobierno virreinal que debió tomar cartas en el asunto, pues estaban en riesgo los intereses económicos que tenía en la región de Bolaños. Muchas de las resoluciones de la autoridad virreinal fueron en favor de los indios, siempre y cuando no afectaran la producción de plata, como sucedió con Vivanco, cuando recibió por parte de la Corona un amparo que le permitió conservar las tierras de Azqueltán ${ }^{26}$.

La situación cambió cuando en el real minero de Bolaños se presentó una baja drástica de producción de plata en 1783. Por esto se dio inicio a la aplicación de una nueva política de los borbones en la región, siendo uno de los objetivos principales lograr hacer más productivo el territorio mediante la reactivación e intensificación de la actividad agrícola y ganadera.

Como se demostró, la Corona en la mayoría de los litigios de tierras dio su apoyo a los indios de los alrededores de Bolaños como una forma de evitar que se sublevasen y pusieran en riesgo la estabilidad de la zona y, por tanto, la producción de plata. Empero, cuando decayó la producción argentífera, a partir de 1790, 
el gobierno de los borbones decidió hacer una serie de reformas para hacer de nueva cuenta productivo el territorio. Una de tales innovaciones fue el repartimiento de tierras indias a españoles, este objetivo se logró a finales de dicha década, principalmente en los pueblos cercanos a la cabecera, es decir, Colotlán.

Para concluir, parafraseando a Marx (1867), en la historia de la acumulación originaria hacen época todas las transformaciones que sirven de punto de apoyo a la naciente clase capitalista, y sobre todo, los momentos en que grandes masas de hombres son despojadas repentina y violentamente de sus medios de subsistencia (tierra), y lanzadas al mercado de trabajo como proletarios libres y desheredados.

\section{ReFERENCIAS}

Archivo General de Indias (AGI) MP-MEXICO,773 - 1 - Imagen Núm: 1 / 1 Recuperado de: https://bit.ly/2kZIkcw https://bit.ly/30EYFTn

Archivo General de la Nación (AGN) / Instituciones Coloniales/ Indiferente Virreinal/ Cajas 1-999/ Caja 0071/ ff. 2-10. Zacatecas 30 de julio de 1721; Real Audiencia/ Indios (058)/ Contenedor 35/Volumen 66/ Exp. 82, ff. 22,66,67,120,121,122, 129. San Luis de Colotlán, 1777; Mercedes (072) / Contenedor 24/ v Volumen 80, S/ N Exp. f. 103, Colotlán, 1778; Tierras (110) / Contenedor 1446/ Volumen 3328/Exp. 9, ff. 280-283, Pueblo San Francisco de Guejucar, 1754.

Archivo General de Simancas (AGS), SGU, LEG, 7015, 9 - 135 Verso- 136 Verso- Imagen Núm: 270 /273. "Milicias de Colotlán. Competencias" México, noviembre 22 de 1785. Recuperado de: https://bit.ly/2kSROGg

"Milicias de Colotlán. San Diego de Talcozagua”. Guadalajara, agosto 25 de 1781. https://bit.ly/30EYFTn , LEG, 7016,916 Recto y 17 Verso - Imagen Núm: 31/34. “Milicias de Colotlán. San Diego de Talcozagua”. México, enero 24 de 1735 . https://bit.ly/2kU1Oiv

Carbajal, D. (1999). El comercio y los comerciantes del Real de Bolaños 1766-1810. Guadalajara, México: FOMES. Universidad de Guadalajara.

Carbajal, D. (2002). La mineria en Bolaños 1748-1810. Zamora, México: El Colegio de Michoacán.

Cataño, C. (2011). Jörn Rüsen y la conciencia histórica. Historia y Sociedad, (21), 223-245. Recuperado de http:// www.scielo.org.co/pdf/hiso/n21/n21a10

Centro de Estudios de Historia de México (CEHM), Fondo XVII-1, Carpeta 2-8, Documento 41, f. 5. Real de Bolaños, junio 23 de 1778. Recuperado de https://bit.ly/2kZ8n3w , Documento 43, ff. 4-5. México, agosto 11 de 1778. https://bit.ly/2msrEdW , Documento 69, f. 1. Colotlán, 14 de enero de 1781. https://bit.ly/2mZOHNA

Coss y León, D. (2000). Rebeliones indígenas en Sonora. El periodo de Diego Ortiz Parrilla: 1749-1753. (Tesis de Licenciatura).Universidad de Guadalajara, Guadalajara, México.

Dávila I. (2001). "El legado Tlaxcalteca. Los Cabildos Tlaxcaltecas de San Esteban" Provincias Internas. Saltillo: Centro Cultural Vito Alessio Robles, núm 1, año 1, pp. 161-183.

Enciso, J. (2000). Zacatecas en el siglo XVI. Derecho y sociedad colonial. México: Ayuntamiento de ZacatecasUniversidad de Alicante-Instituto Zacatecano de Cultura Ramón López Velarde.

Enríquez, L. (2011). Cinco siglos de rebeliones indígenas en México. Recuperado de http:// tlanestli.blogspot.mx/2011/04/cinco-siglos-de-rebeliones-indigenas-en.html

Fábregas A. y Tomé, P. (2002). Regiones y Fronteras: una perspectiva antropológica. Zapopan, México: El Colegio de Jalisco-Secretaría de Educación Pública.

Gálvez, M. (1996). La conciencia regional en Guadalajara y el gobierno de los Intendentes (1786-1800). Guadalajara, México: Gobierno del Estado de Jalisco.

Gerhard, P. (1996). La frontera norte de la Nueva España. México: Universidad Nacional Autónoma de México.

Gilabert, C. (2002). El imperio de los arcanos o los poderes invisibles del Estado moderno. Zapopan, México: El Colegio de Jalisco.

López, Á. (1974). El establecimiento del Real de Minas de Bolaños. Historia Mexicana. 23, Vol(3), 408-436. 
Marx, C. (1867). El Capital. El Proceso de Producción del Capital Tomo I, Capitulo XXIV. La llamada acumulación originaria. Recuperado de http://www.fmmeducacion.com.ar/Bibliotecadigital/Marx_Elcapital-Tomo-I.pdf

O’Gorman, E. (2000). Historia de las divisiones territoriales de México. México: Editorial Porrúa.

Pérez, L. (1988). Historia particular del estado de Jalisco. Desde los primeros tiempos que hay noticia, hasta nuestros dias. Guadalajara, México: Universidad de Guadalajara.

Rojas, J. (2009). Las milicias de Nueva Galicia. Elite, Indigenas y Castas, los soldados del rey (1758-1810). México: Instituto Nacional de Antropología e Historia, Jalisco.

Ruiz, C. (2007). El tumulto de abril de 1757 en Actopan. Coerción laboral y las formas de movilización y resistencia social de las comunidades indígenas. Estudios de historia novohispana, Vol(36), 101-129. Recuperado dehttp:// www.historicas.unam.mx/publicaciones/revistas/novohispana/pdf/novo36/0453.pdf

Ruiz, C. (2014). El Real de Minas de Bolaños, Jalisco, en el siglo XVIII: transformaciones territoriales y cambios sociales. Región y sociedad. Vol(60), 191-227. Recuperado de https://www.colson.edu.mx:4433/Revista/ Articulos/60/7Ruiz.pdf

Shadow, R. (2000). La frontera norteña de la Nueva Galicia: las parroquias de Colotlán, 1725-1820. En Lecturas históricas del norte de Jalisco, compilado por José María Muriá y Manuel Caldera. Zapopan, México: El Colegio de Jalisco-Universidad de Guadalajara-Campus Universitario del Norte.

Soriano, S. (1994). Lucha y resistencia indígena en el México colonial. México: Centro de investigaciones humanísticas de Mesoamérica y el estado de Chiapas-UNAM.

Tuñón, M. (1984). Metodología de la historia social en España. Madrid: Siglo XXI.

Van Young, E. (1991). Haciendo historia regional: consideraciones metodológicas y teóricas. En Pedro Pérez Herrero (compilador), 99-122. Región e Historia en México. México: Instituto de Investigaciones Dr. José María Luis Mora.

Velázquez, M. (1961). Colotlán doble frontera contra los bárbaros. México: Universidad Nacional Autónoma de México.

Villamil, R. (1996). Las instituciones intimas. México: Universidad Autónoma Metropolitana, México.

Zingg, R. (1998). La Mitología de los huicholes. Guadalajara, México: Secretaría de Cultura-El Colegio de MichoacánEl Colegio de Jalisco.

\section{Notas}

1 Los privilegios que señalan las capitulaciones incluyen: "que todos los indios que fuesen de la ciudad de Tlaxcala a poblar de nuevo con los dichos chichimecas sean ellos y sus descendientes perpetuamente hidalgos" además, que sean "libres de tributo, pecho y alcabala y servicio personal " y que cuando fundasen "sus asentamientos no les manden poblar juntamente con los españoles, sino distintos" que "las tierras, pastos, montes, ríos, pesquerías, molinos y otros géneros de hacienda estén señaladas en cada parte" además "que a cinco leguas de las poblaciones no se pueda hacer merced de la estancia para ganado mayor" y "que las tierras y estancias que se les diesen y repartiesen a los tlaxcaltecas así de particulares, como para comunidad no se les pueda quitar por despobladas" que los "mercados que hiciesen en las poblaciones sean francos libres de alcabala y de cualquier género de imposición" también "que los indios principales de la dicha ciudad [de Tlaxcala], que fueren a la población y sus descendientes puedan tener y traer armas, y andar a caballo ensillado sin incurrir en pena, y para hacer el viaje se les de bastimento necesario y ropa" y que "por espacio de dos años, les ayuden con esto, y con romper la tierra para las sementeras" pero sobre todo "que se les dé carta y real provisión en que se mande guardar estas provisiones". El anterior extracto de las capitulaciones que se otorgaron a los tlaxcaltecas fue tomado de una copia certificada de dichas capitulaciones, que el 23 de julio de 1721 se realizó en Colotlán por solicitud de los indios principales del barrio tlaxcalteca. Esto como una necesidad de preservar dicho documento ante el deterioro en que se encontraba el original. Y que se localizó Archivo General de la Nación (AGN)/ Instituciones Coloniales/ Indiferente Virreinal/ Cajas 1-999/ Caja 0071/ Expediente del testimonio de la Real Provisión, sus obedecimientos, cumplimientos y posesión de tierras en favor de los Indios Tlaxcaltecas que formaron el Pueblo y Frontera de San Luis Colotlán. Colotlán, 23 de julio de 1721.

2 Por grupo de contrapoder se entiende el conjunto de indios norteños que tenían el status de fronterizos, mismo que la Corona les otorgó en el siglo XVI por su apoyo para la defensa de la frontera. Los indios que gozaban de dicho status, 
entre otras cosas podían portar armas, montar a caballo y ser libres de tributo. Shadow (2000), señala, que los indios fronterizos hicieron todo lo posible por conservar su status político-social, porque para ellos era una herramienta de defensa y lucha colectiva (p. 108).

3 Archivo General de Simancas (en adelante AGS), SGU, LEG,7016, 9, 2 Recto- 7 Recto, Imagen Núm: 3/13. "Milicias de Colotlán. San Diego de Talcozagua”. Guadalajara, agosto 25 de 1781. Recuperado de https://bit.ly/1fdVdzx

4 En este trabajo se entiende por conciencia histórica aquel conjunto de funciones a través de las cuales un individuo y/ o una sociedad crea una relación activa con su pasado a través de una experiencia temporal, la cual debe ser percibida e interpretada antes de volverse elemento de orientación y motivación (Cataño, 2011, p.223). 5AGS, SGU, LEG, 7016,9 16 Recto y 17 Verso - Imagen Núm: 31/34. “Milicias de Colotlán. San Diego de Talcozagua”. México, enero 24 de 1735. Recuperado de https://bit.ly/2mTg2AP

6 AGS. Secretaría de Guerra, leg. 7015, exp. 9, ff. pp. 23-24.

7 Archivo General de la Nación (en adelante AGN) / Instituciones Coloniales/ Real Audiencia/ Tierras (110) / Contenedor 1446/ Volumen 3328/ Exp. 9, ff. 280-283, Pueblo San Francisco de Guejucar, 1754.

8 AGN / Instituciones Coloniales/ Real Audiencia/ Mercedes (072) / Contenedor 24/ v Volumen 80, S/N Exp. f. 103, Colotlán, 1778.

9 AGN / Instituciones Coloniales/ Real Audiencia/ Mercedes (072) / Contenedor 24/ v Volumen 80, S/N Exp. f. 103, Colotlán, 1778.

10 AGN / Instituciones Coloniales/ Real Audiencia/ Indios (058) / Contenedor 35/ Volumen 66/ Exp. 82, f. 122. San Luis de Colotlán, 1777. 11Centro de Estudios de Historia de México (en adelante CEHM), Fondo XVII-1, Carpeta 2-8, Documento 41, f. 5. Real de Bolaños, junio 23 de 1778. Recuperado de: https://bit.ly/2lEgMcH

12 CEHM, Fondo XVII-1, Carpeta 2-8, Documento 43, ff. 4-5. México, agosto 11 de 1778. https://bit.ly/2kAjy2c

13 AGN / Instituciones Coloniales/ Real Audiencia/ Indios (058) / Contenedor 35/ Volumen 66/ Exp. 82, f. 121, San Luis Colotlán, 1777.

14 AGN / Instituciones Coloniales/ Real Audiencia/ Indios (058) / Contenedor 35/ Volumen 66/ Exp. 82, f. 120, San Luis Colotlán, 1777.

15 AGN / Instituciones Coloniales/ Real Audiencia/ Indios (058) / Contenedor 35/ Volumen 66/ Exp. 82, f. 121, San Luis Colotlán, 1777.

16 AGN / Instituciones Coloniales/ Real Audiencia/ Indios (058) / Contenedor 35/ Volumen 66/ Exp. 82, f. 121, San Luis Colotlán, 1777.

17 AGN / Instituciones Coloniales/ Real Audiencia/ Indios (058) / Contenedor 35/ Volumen 66/ Exp. 82, f. 121, San Luis Colotlán, 1777.

18 AGN / Instituciones Coloniales/ Real Audiencia/ Indios (058) / Contenedor 35/ Volumen 66/ Exp. 82, f. 121, San Luis Colotlán, 1777.

19 AGN / Instituciones Coloniales/ Real Audiencia/ Indios (058) / Contenedor 35/ Volumen 66/ Exp. 82, f. 121, San Luis Colotlán, 1777.

20 AGN / Instituciones Coloniales/ Real Audiencia/ Indios (058) / Contenedor 35/ Volumen 66/ Exp. 82, f. 121, San Luis Colotlán, 1777.

21 AGN/ Instituciones Coloniales/ Real Audiencia/ Indios (058) / Contenedor 35/Volumen 66/ exp. 82, ff. 66-67, San Luis Colotlán, 1777.

22 AGN/ Instituciones Coloniales/ Real Audiencia/ Indios (058) / Contenedor 35/ Volumen 66/ exp. 82, ff. 66-67, San Luis Colotlán, 1777.23AGN/ Instituciones Coloniales/ Real Audiencia/ Indios (058) / Contenedor 35/Volumen 66/ exp. 82, f. 129, San Luis Colotlán, 1777.

24 AGN/ Instituciones Coloniales/ Real Audiencia/ Indios (058) / Contenedor 35/Volumen 66/ exp. 82, f. 22 vta., San Luis Colotlán, 1777.

25 AGN/Instituciones Coloniales/ Real Audiencia/ Indios (058) / Contenedor 35/Volumen 66/ exp. 82, f. 22 vta., San Luis Colotlán, 1777.

26 AGN/ Instituciones Coloniales/ Real Audiencia/ Indios (058) / Contenedor 35/Volumen 66/ exp. 82, f. 122 vta., San Luis Colotlán, 1777.

Todos los derechos reservados. Universidad de Costa Rica. Esta revista se encuentra licenciada con Creative Commons. Reconocimiento-NoComercial-SinObraDerivada 3.0 Costa Rica. Correo electrónico: humanidades@ucr.ac.cr/Sitio web: http: //revistas.ucr.ac.cr/index.php/humanidades

\section{BY-NC-ND}

